\title{
Carcinoid Heart Disease: Prognostic Value of 5-Hydroxyindoleacetic Acid Levels and Impact on Survival: A Systematic Literature Review
}

\author{
Amy Buchanan-Hughes ${ }^{a} \quad$ Alex Pashley $^{a} \quad$ Marion Feuilly $^{b}$ Florence Marteau $^{b}$ \\ D. Mark Pritchard ${ }^{c}$ Simron Singh ${ }^{d}$ \\ ${ }^{a}$ Costello Medical, Cambridge, UK; ${ }^{b}$ Ipsen Pharma, Boulogne-Billancourt, France; ' University of Liverpool, Liverpool,

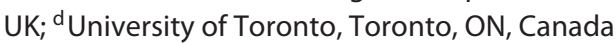

\section{Keywords}

Carcinoid syndrome $\cdot$ Carcinoid heart disease .

Neuroendocrine tumours

\begin{abstract}
Background: Carcinoid heart disease (CHD) can develop in patients with carcinoid syndrome (CS), itself caused by overproduction of hormones and other products from some neuroendocrine tumours. The most common hormone is serotonin, detected as high 5-hydroxyindoleacetic acid (5-HIAA). This systematic literature review summarises current literature on the impact of CHD on survival, and the relationship between 5-HIAA levels and CHD development, progression, and mortality. Methods: MEDLINE, Embase, Cochrane databases, and grey literature were searched using terms for CHD, 5-HIAA, disease progression, and mortality/survival. Eligible articles were non-interventional and included patients with CS and predefined CHD and 5-HIAA outcomes. Results: Publications reporting on 31 studies were included. The number and disease states of patients varied between studies. Estimates of CHD prevalence and incidence among patients with a diagnosis/symptoms indicative of CS were 3-65\% and 3-42\%, respectively. Most studies evaluating survival found significantly higher mortality rates among pa-
\end{abstract}

karger@karger.com www.karger.com/nen

Karger $\frac{1}{\%}$

GOPEN ACCESS
(C) 2020 The Author(s)

Published by S. Karger AG, Basel

This article is licensed under the Creative Commons AttributionNonCommercial-NoDerivatives 4.0 International License (CC BYNC-ND) (http://www.karger.com/Services/OpenAccessLicense) Usage and distribution for commercial purposes as well as any distribution of modified material requires written permission. tients with versus without $\mathrm{CHD}$. Patients with $\mathrm{CHD}$ reportedly had higher 5-HIAA levels; median urinary levels in patients with versus without CHD were $266-1,381$ versus $67.5-575 \mu \mathrm{mol} / 24 \mathrm{~h}$. Higher 5 -HIAA levels were also found to correlate with disease progression (median progression/ worsening-associated levels: $791-2,247 \mu \mathrm{mol} / 24 \mathrm{~h}$ ) and increased odds of death ( $7 \%$ with every $100 \mathrm{nmol} / \mathrm{L}$ increase). Conclusions: Despite the heterogeneity of studies, the data indicate that $\mathrm{CHD}$ reduces survival, and higher 5-HIAA levels are associated with CHD development, disease progression, and increased risk of mortality; 5-HIAA levels should be carefully managed in these patients.

(C) 2020 The Author(s)

Published by S. Karger AG, Basel

\section{Introduction}

Carcinoid syndrome (CS) refers to a spectrum of symptoms caused by excessive production of hormones and other tumour products from some neuroendocrine tumours (NETs) [1]. The incidence of NETs in the United States (US) was estimated to be 6.98 per 100,000 in 2012 , with an approximate annual prevalence of $0.048 \%$ [2]. A subset of patients with NETs (approximately 20\%) develop CS [3]. The secreted tumour products responsi- 
Table 1. Eligibility criteria for the SLR

\begin{tabular}{|c|c|c|}
\hline Patient population & Adults with CS & $\begin{array}{l}\text { - Adults without CS } \\
\text { - Children }(<18 \text { years old }) \text { with CS } \\
\text { - Populations where outcomes are not presented } \\
\text { separately for the patients of interest }\end{array}$ \\
\hline Intervention(s) & Any or none & - \\
\hline Outcomes & $\begin{array}{l}\text { - Number of patients with and without CHD } \\
\text { - Number of patients who died from CHD, and the mean survival } \\
\text { in patients with and without CHD } \\
\text { - Baseline 5-HIAA level in patients with and without CHD, and in } \\
\text { patients who died from CHD } \\
\text { - Increase in 5-HIAA level associated with disease progression } \\
\text { - Risk of disease progression associated with 5-HIAA level } \\
\text { - Risk of CHD death associated with 5-HIAA level }\end{array}$ & $\begin{array}{l}\text { Studies not presenting relevant outcomes for the } \\
\text { population of interest }\end{array}$ \\
\hline Other considerations & $\begin{array}{l}\text { - Abstract or full text in English } \\
\text { - Human participants } \\
\text { - Conference abstracts from } 2016 \text { onwards }\end{array}$ & $\begin{array}{l}\text { - Abstract or full text not in English } \\
\text { - Non-human participants } \\
\text { - Conference abstracts from prior to } 2016\end{array}$ \\
\hline
\end{tabular}

5-HIAA, 5-hydroxyindoleacetic acid; CHD, carcinoid heart disease; CS, carcinoid syndrome; PICOS, patients, interventions, comparators, outcomes and settings; RCT, randomised controlled trial; SLR, systematic literature review.

ble for disease development (serotonin being the most prominent) are ordinarily degraded by the liver $[4,5]$. However, CS is often associated with liver metastases, allowing unmetabolised NET secretions to circulate at higher levels, leading to disease development and progression $[5,6]$.

Elevated serotonin levels cause a range of symptoms including cutaneous flushing, diarrhoea, and bronchoconstriction [6], experienced by $90 \%, 80 \%$ and $15 \%$ of patients with CS, respectively $[7,8]$. In addition to these symptoms, it has been reported that approximately half of individuals with CS will develop carcinoid heart disease (CHD), a potentially life-threatening complication $[6,9]$. Although the exact pathophysiology of CHD is not well understood, the secretion of hormones and other products from tumours is suspected to lead to the deposition of cardiac plaques, which are primarily found on the right side of the heart ( $90 \%$ of cases) [1, 10]. There is currently a lack of consensus regarding the diagnosis, management, and preventative measures for $\mathrm{CHD}$, despite patients having significantly worse life expectancy than those with CS alone $[1,6]$.

The principal laboratory test to analyse serotonin overproduction in individuals with CS is the measurement of 5-hydroxyindoleacetic acid (5-HIAA), a metabolite of serotonin, in urine or plasma $[4,5]$. The aim of this systematic literature review (SLR) was to summarise the published quantitative evidence on the association between high urine and/or plasma 5-HIAA concentration and CHD development, and the impact of CHD on survival.

\section{Methods}

\section{Search Strategy}

A systematic search of MEDLINE, Embase, Cochrane Database of Systematic Reviews (CDSR), and Database of Abstracts of Reviews of Effect (DARE) was conducted on the 4th May 2018, using 


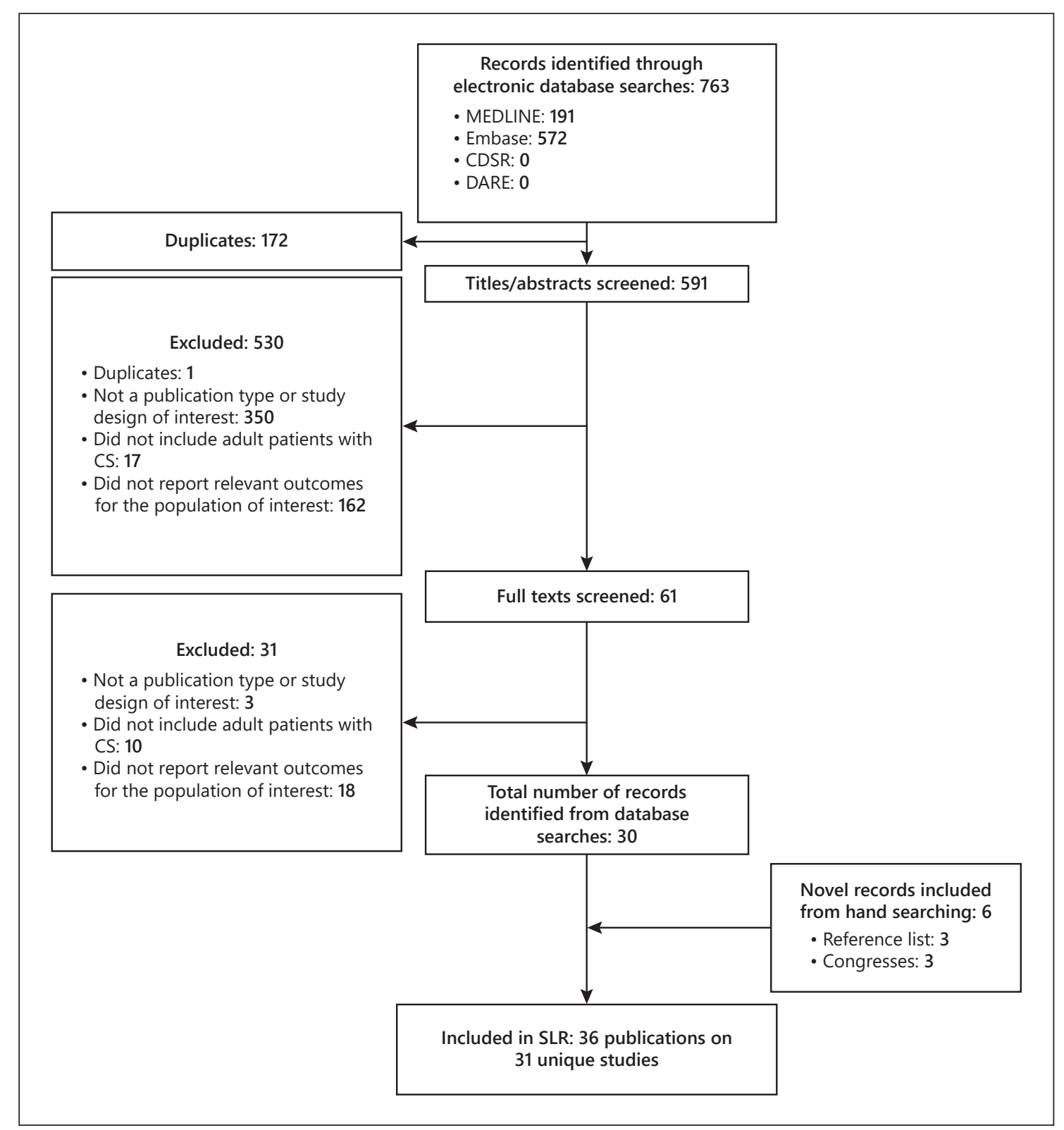

Fig. 1. Preferred Reporting Items for Systematic Reviews and Meta-Analyses (PRISMA) flow diagram. CDSR, Cochrane Database of Systematic Reviews; CS, carcinoid syndrome; DARE, Database of Abstracts of Reviews of Effects; SLR, systematic literature review.

predefined search terms for CHD, 5-HIAA, disease progression, mortality, and survival. Supplementary searches of article reference lists and congress abstracts from oncology and neuroendocrine-specific congresses were also carried out to ensure that no relevant studies were missed. Conference abstracts from prior to 2016 and any studies not published in English were excluded. Full details of the searches are provided in the supplementary information (online suppl. Tables S1-S4; for all online suppl. material, see www.karger.com/doi/10.1159/000506744). The SLR was conduct- ed in line with the recommendations of the Cochrane Handbook for Systematic Reviews of Interventions and the University of York Centre for Reviews and Dissemination's (CRD) Guidance for Undertaking Reviews in Health Care $[11,12]$.

Eligible articles had to describe observational studies that included patients with CS and reported data on predefined CHD outcomes. An overview of the patients, interventions, comparators, outcomes, and study designs used for the SLR is shown in Table 1. 
Table 2. Study characteristics of the included articles

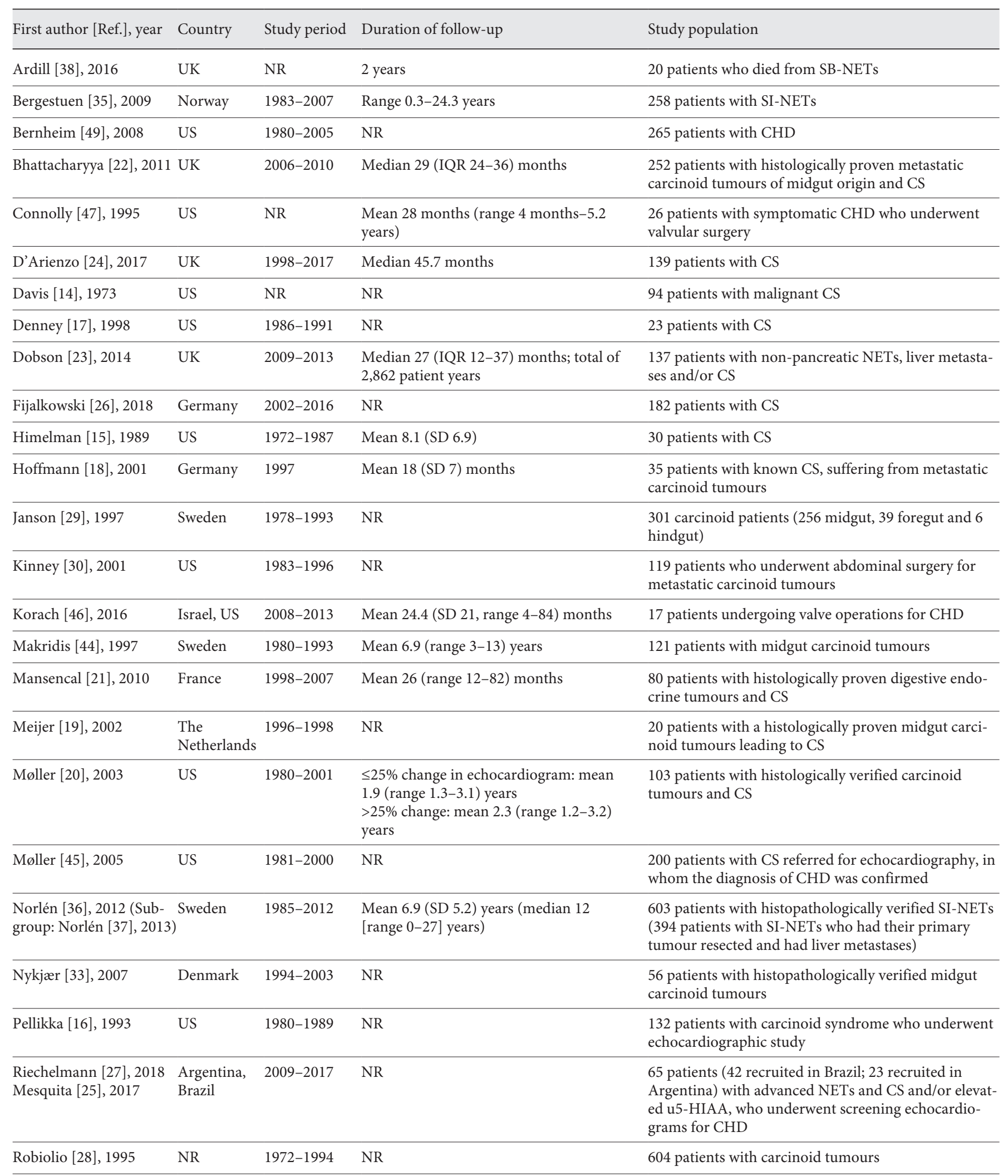


Table 2 (continued)

\begin{tabular}{|c|c|c|c|c|}
\hline First author [Ref.], year & Country & Study period & Duration of follow-up & Study population \\
\hline $\begin{array}{l}\text { Rodríguez Laval [39], } \\
2018\end{array}$ & Germany & $2008-2014$ & $\begin{array}{l}\text { MF not present: median } 47 \text { (range } 31- \\
\text { 78) months } \\
\text { MF present: median } 51 \text { (range 28-75) } \\
\text { months }\end{array}$ & $\begin{array}{l}81 \text { patients with pathologically proven NETs with the } \\
\text { primary site in the midgut and mesenteric lymphatic } \\
\text { metastases on imaging }\end{array}$ \\
\hline $\begin{array}{l}\text { Toumpanakis [41-43], } \\
2016\end{array}$ & UK & NR & NR & 600 patients with advanced SB-NETs ${ }^{\mathrm{a}}$ \\
\hline Weingarten [48], 2007 & US & $1985-2003$ & NR & $\begin{array}{l}100 \text { patients with symptomatic CHD who underwent } \\
\text { surgery }\end{array}$ \\
\hline Westberg [40], 2001 & Sweden & $1985-1998$ & Mean 85 (SEM 8) months & 64 patients with midgut CS \\
\hline
\end{tabular}

CHD, carcinoid heart disease; CS, carcinoid syndrome; IQR, interquartile range; MF, mesenteric fibrosis; NET, neuroendocrine tumour; NR, not reported; SD, standard deviation; SEM, standard error of the mean; SB-NET, small bowel neuroendocrine tumour; SI-NET, small intestinal neuroendocrine tumour; u5-HIAA, urinary 5-hydroxyindoleacetic acid. ${ }^{\text {a }}$ The most recent conference abstract listed 600 patients, whereas the two previous abstracts indicated only 572 patients were analysed; the outcomes reported were identical, so the more recent figure was used.

\section{Article Screening and Data Extraction}

Titles and abstracts of all potentially relevant publications were screened against the predefined eligibility criteria by two independent reviewers. For references that were considered potentially relevant, the full publication was retrieved, and its relevance was assessed against the eligibility criteria by two independent reviewers. At both stages, in the event of disagreement, a third reviewer was consulted to make the final decision. Publications suitable for inclusion were extracted into a predefined extraction grid by one reviewer and checked for accuracy and completeness by a second reviewer. The quality of study reporting was assessed using the Strengthening the Reporting of Observational Studies in Epidemiology (STROBE) checklist [13].

\section{Results}

\section{Characteristics of the Captured Studies}

From the 591 unique citations identified by the database searches, 30 publications reporting 29 studies were included in the SLR, with a further 6 unique publications identified from additional hand searches. Therefore, a total of 36 publications representing 31 studies were included for extraction (Fig. 1). An overview of the study characteristics of the extracted articles is given in Table 2.

The number of included patients varied widely between studies, from 17 to 604 , and a range of disease states were reported on, including small bowel NETs and nonpancreatic NETs with liver metastases. The study period (reported in 27 studies) ranged from 1 to 27 years. The majority of studies (18) were conducted in Europe, 11 were conducted in the US (one of which was also conducted in Israel), one was conducted in South America, and one did not report a geographical location (Table 2). Data on patient ethnicity were not collected in this SLR.

\section{Prevalence and Incidence of CHD}

A total of 24 studies reported details on the prevalence or incidence of CHD within their patient populations: 23 studies reported the number of patients with $\mathrm{CHD}$ at baseline, and 7 studies reported the development of $\mathrm{CHD}$ in patients over their designated study period (Fig. 2). Fourteen of the 24 studies explicitly stated that their patients had CS [14-27]; 10 studies described patients with NETs including gastrointestinal NETs, or described symptoms typical of CS (such as diarrhoea or flushing), but did not specifically report CS [28-39].

The percentage of patients with $\mathrm{CHD}$ at baseline ranged from $3 \%$ to $65 \%[20,28]$. The percentage of patients with CS who developed CHD ranged from $3 \%$ to $22 \%[17,23,36,37]$, affording crude calculated incidence values ranging from $3 \%$ to $42 \%$ among patients who did not have CHD at baseline [20,36, 37]; however, variation in the lengths of these studies prevented comparison and any meaningful conclusions from being drawn (Fig. 2). Several studies featured patients who were referred for echocardiography based on suspicion of CHD, implying potential selection bias $[16,20,25,27]$. Removing these 


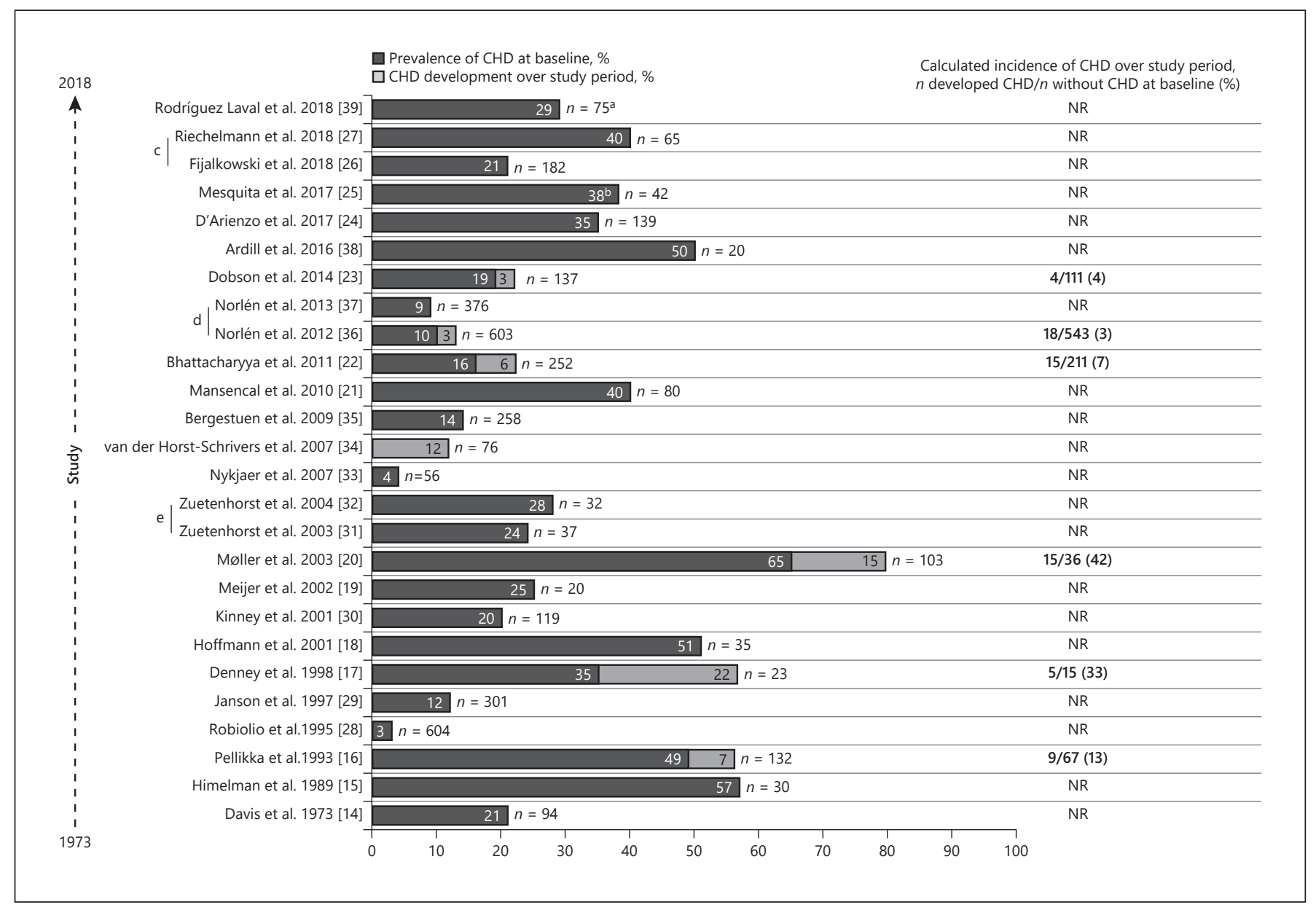

Fig. 2. Prevalence and incidence of carcinoid heart disease (CHD). ${ }^{\mathrm{a}} n=81,6$ cases missing; ${ }^{\mathrm{b}} 45 \%$ (19 patients) when $\mathrm{CHD}$ is defined as at least mild valve regurgitation. ${ }^{c-e}$ Different publications on the same study. NR, not reported.

studies would decrease the highest reported CHD prevalence estimates from $65 \%$ to $57 \%$ [15], and the highest calculated crude incidence figures from $42 \%$ to $33 \%$ [17].

\section{Survival in Patients with and without CHD}

Fourteen studies reported the survival of patients with CHD, 11 of which also reported survival in patients without CHD (Table 3) [15-18, 23, 28, 29, 31, 32, 35-37, 4043]. Survival was found to be lower in patients with CHD versus patients without $\mathrm{CHD}$ in all studies that reported both, with the comparison reaching statistical significance in 8 studies [15, 16, 18, 23, 31, 32, 36, 37, 41-43]. Two studies reported a non-significant result $[29,35]$; the remaining studies did not analyse these outcomes for significance, or used descriptive statistics only $[17,28,40$, 44-46].
Four studies evaluated survival or mortality at specified timepoints for patients with and without CHD [16, $17,35,40]$. Pellikka et al. [16] reported that 3-year survival for patients with CHD was $31 \%$, compared with $68 \%$ for patients with no echocardiographic evidence of cardiac involvement $(p=0.0003)$. Similarly, Bergestuen et al. [35] reported 50\% 5-year survival for patients with CHD, compared with $76 \%$ for those without ( $p=0.02$ [univariate analysis]; $p=0.25$ [multivariate analysis]). Westberg et al. [40] and Denney et al. [17], who reported outcomes at 5 and 6 years, respectively, found worse survival among patients with CS and CHD than those without CHD. They also reported worse survival in patients with relatively severe CHD disease, though it is not clear whether the results of these subgroup comparisons were statistically significant $[17,40]$. Additionally, Korach et al. [46], 
Table 3. Survival in patients with and without CHD

\begin{tabular}{|c|c|c|c|c|c|c|}
\hline \multirow[t]{2}{*}{ First author [Ref.], year } & \multicolumn{3}{|l|}{ Median $(95 \% \mathrm{CI})$ survival, years } & \multicolumn{2}{|l|}{ Absolute survival, $n / \mathrm{N}(\%, 95 \% \mathrm{CI})$} & \multirow[t]{2}{*}{ Additional comments } \\
\hline & with CHD & without CHD & $\begin{array}{l}\text { time point, } \\
\text { years }\end{array}$ & with CHD & without $\mathrm{CHD}$ & \\
\hline Bergestuen [35], 2009 & \multicolumn{3}{|c|}{$\begin{array}{c}\text { Univariate HR: } 1.76(1.09-2.84) \\
\text { Multivariate HR: } 0.70(0.38-1.29)\end{array}$} & NR (50) & NR (76) & $\begin{array}{l}\text { Univariate analysis: } p=0.02 \\
\text { Multivariate analysis: } p=0.25\end{array}$ \\
\hline Bernheim [49], 2008 & NR & NR & 5 & $\begin{array}{l}\text { Patients who had hepatic resection } \\
\text { performed during follow-up: NR } \\
\text { (86.5, 73.5-100) } \\
\text { Patients without hepatic resection: NR } \\
(29.0,23.3-36.1)\end{array}$ & NR & $\begin{array}{l}\text { Survival after diagnosis; survival curve } \\
\text { available for hepatic resection vs. no } \\
\text { hepatic resection }\end{array}$ \\
\hline Denney [17], 1998 & NR & NR & 6 & $\begin{array}{l}\text { Developed new CHD: } 3 / 5(60 \%) \\
\text { CHD, no progression: } 1 / 7(14 \%) \\
\text { CHD progression: } 1 / 1(100 \%)\end{array}$ & $3 / 10(30)$ & $p=\mathrm{NR}$ \\
\hline Dobson [23], 2014 & $\begin{array}{l}6.5(0.1-\text { not reached })^{\mathrm{a}, \mathrm{b}} \\
\qquad \text { HR: } 3.61(1.69-7 .\end{array}$ & $\begin{array}{l}20.2(1.0-\text { not } \\
\text { reached })^{\mathrm{a}, \mathrm{b}} \\
.69)\end{array}$ & NR & NR & NR & $\begin{array}{l}\text { Kaplan-Meier survival curve available; } \\
p=0.001 \text { for univariate analysis }\end{array}$ \\
\hline Himelman [15], 1989 & Mean 1.9 (SD 1.4) & Mean 3.8 (SD 2.9) & NR & NR & NR & $\begin{array}{l}\text { Survival after the first echocardiogram; } \\
p=0.05\end{array}$ \\
\hline Hoffmann [18], 2001 & $\begin{array}{l}11 \text { months (5 months - not } \\
\text { reached) })^{\mathrm{a}, \mathrm{b}}\end{array}$ & $\begin{array}{l}\text { Not reached }(9 \\
\text { months - not } \\
\text { reached })^{\text {a, b }}\end{array}$ & NR & NR & NR & $\begin{array}{l}\text { Kaplan-Meier survival curve available; } \\
p=0.04\end{array}$ \\
\hline Janson [29], 1997 & 46 months & 94 months & NR & NR & NR & $\begin{array}{l}\text { Midgut carcinoid patients with/without } \\
\text { CHD (NS, } p=0.09)\end{array}$ \\
\hline Korach [46], 2016 & $27(1-81)$ months $^{\mathrm{a}}$ & NR & 4 & Mean 23\% (SD 14\%) & NR & $\begin{array}{l}\text { Actuarial survival after valve replacement } \\
\text { for CHD; } \\
\text { Kaplan-Meier survival curve available; } \\
p=\mathrm{NR}\end{array}$ \\
\hline Makridis [44], 1997 & $5.0(\mathrm{NR})$ & NR & NR & NR & NR & $\begin{array}{l}90 \% \text { CIs were determined using patients } \\
\text { with no CS, rather than no CHD, and as } \\
\text { such have not been presented here; } \\
p=\mathrm{NR}\end{array}$ \\
\hline Møller [45], 2005 & $2.6(1.6-3.2)$ & NR & NR & NR & NR & $\begin{array}{l}\text { Median survival from first diagnosis of } \\
\text { metastatic carcinoid disease was } 5.9 \\
(95 \% \text { CI } 5.0-6.8) \text { years; } p=\mathrm{NR}\end{array}$ \\
\hline Norlén [36, 37], 2012 & HR: $2.52(1.76-3$. & $.61)$ & NR & NR & NR & Overall survival; $p<0.001$ \\
\hline Pellikka [16], 1993 & 1.6 & 4.6 & 3 & NR (31) & $\begin{array}{l}\text { NR }(68) \text { for those } \\
\text { without echocardio- } \\
\text { graphic evidence of } \\
\text { cardiac involvement }\end{array}$ & $p=0.0003$ \\
\hline Robiolio [28], 1995 & $4.8(3.8-13.3)$ & $7(5.0-9.2)$ & NR & NR & NR & Survival is from time of diagnosis; $p=\mathrm{NR}$ \\
\hline Toumpanakis [41-43], 2016 & HR: 5 (NR), SE: 2 & 2.26 & $\begin{array}{l}3 \\
5\end{array}$ & $\begin{array}{l}\text { NR (38) } \\
\text { NR (25) }\end{array}$ & NR & $p<0.001$ \\
\hline Westberg [40], 2001 & $\begin{array}{l}\text { Severe CHD: } 54 \text { (6-95) months }{ }^{\mathrm{a}} \\
\text { Moderate CHD: not reached ( } 9 \\
\text { months - not reached) })^{\mathrm{a}, \mathrm{b}} \\
\text { Mild CHD: not reached ( } 8 \text { months } \\
\text { - not reached) })^{\mathrm{a}, \mathrm{b}}\end{array}$ & $\begin{array}{l}\text { Not reached (12 } \\
\text { months - not } \\
\text { reached) })^{\mathrm{a}, \mathrm{b}}\end{array}$ & 5 & $\begin{array}{l}\text { Severe CHD: } 30 \% \\
\text { Moderate CHD: } 70 \% \\
\text { Mild CHD: } 70 \%\end{array}$ & $75 \%$ & $\begin{array}{l}\text { Kaplan-Meier survival curve available; } \\
p=\mathrm{NR}\end{array}$ \\
\hline Zuetenhorst [31, 32], 2003 & $\begin{array}{l}13 \text { months }(5 \text { months - } \\
\text { not reached })^{\text {a }} \mathrm{b}\end{array}$ & $\begin{array}{l}\text { Not reached ( } 6 \\
\text { months - not } \\
\text { reached })^{\mathrm{a}, \mathrm{b}}\end{array}$ & NR & NR & NR & $\begin{array}{l}\text { Kaplan-Meier survival curve available; } \\
p=0.026\end{array}$ \\
\hline
\end{tabular}

a Value determined from Kaplan-Meier survival curve by digitisation: three readings were taken and the mean of these values was used; ${ }^{\text {b }}$ Value not reached according to the Kaplan-Meier survival curve due to insufficient follow-up period. CHD, carcinoid heart disease; CI, confidence interval; CS, carcinoid syndrome; HR, hazard ratio; NR, not reported; NS, not significant; SD, standard deviation; SE, standard error.

who recruited patients with CHD exclusively, reported 4 -year survival of $23 \%$ after valve replacement.

Four studies reported univariate or multivariate analyses of mortality risk in patients with CS and CHD versus CS without CHD (Fig. 3) [23, 35-37, 41-43]. Through a univariate analysis, Dobson et al. [23] showed that the risk of death was significantly greater in patients with $\mathrm{CHD}$ at baseline, compared with those without CHD (hazard ratio [HR]: 3.61; 95\% confidence interval [CI]: $1.69-7.69 ; p=0.001)$. This study also found that a fivepoint increase in echocardiographic score resulted in an odds ratio (OR) of 2.66 for death (95\% CI: 1.63-4.35; $p<$ 


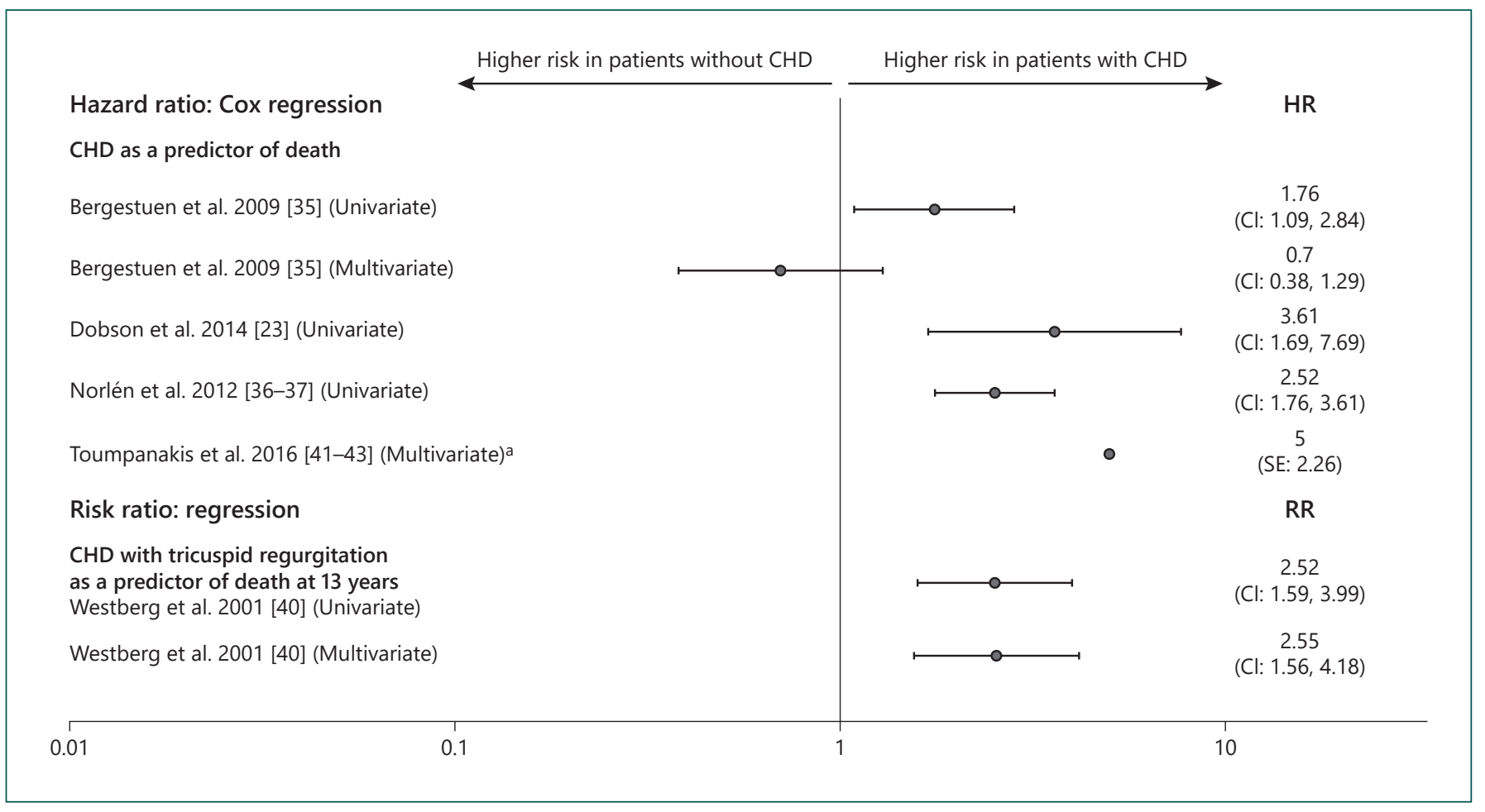

Fig. 3. Carcinoid heart disease (CHD) as a predictor of death. ${ }^{\text {a }}$ Confidence intervals were not reported in this publication. The published SE value was used to estimate the $95 \%$ confidence interval (CI) using the methods described in Hackshaw [54]. A 95\% CI of 0.06-419.49 was obtained, corresponding to a statistically insignificant result, in contrast to the published $p$ value $(<0.001)$. This study has been published in the form of conference abstracts only and no further information on the statistical methods is available. HR, hazard ratio; RR, risk ratio.

0.005) [23]. Bergestuen et al. [35] employed both types of analysis in patients with small intestinal NETs and CS, finding that CHD was a significant predictor of death in univariate analyses (HR: 1.76; 95\% CI: 1.09-2.84; $p=$ 0.02 ), but not in the multivariate analysis (HR: $0.70 ; 95 \%$ CI: $0.38-1.29 ; p=0.25)$. Only distant metastases, the NET marker chromogranin $\mathrm{A} \geq 6.2 \times$ the upper limit of its normal concentration, and age $\geq 64$ years were significant predictors of death in the multivariate analysis [35].

Two of the 4 studies used multivariate analyses exclusively [36, 37, 41-43]. In Norlén et al. [36, 37], CHD was associated with an HR of 2.52 (95\% CI: 1.76-3.61; $p<$ 0.001 ) for overall survival (vs. patients without CHD). In Toumpanakis et al. [41-43], the presence of severe CHD (definition not provided) was reported to have a significant impact on overall survival versus the absence of CHD, with an HR of 5.00 (standard error [SE]: 2.26; $p<$ 0.001 ) when adjusting for tumour grade, metastases, and age. However, calculation of a 95\% CI using the reported $\mathrm{SE}$ value suggests an insignificant result (Fig. 3).
In a study that used echocardiographic examination to predict the prognosis of patients with CS, Westberg et al. [40] evaluated the impact of eight variables on survival using univariate analyses. The study found that the only variables to significantly increase the relative risk of death were older age at diagnosis, tricuspid regurgitation (TR), and tricuspid structural abnormalities (TSA) + TR; a TSA + TR score of one or more was considered pathological. Their multivariate analysis also showed an increased risk of death in patients with TR (Fig. 3).

\section{Association between 5-HIAA Levels and CHD}

Diagnosis, Progression, and Mortality

A total of 19 studies reported baseline levels of urinary 5-HIAA (u5-HIAA) in patients with CHD [15-21, 25, $27-29,31,32,34,35,40,45-49]$; of these, 13 studies also presented baseline levels of $\mathrm{u} 5$-HIAA in patients without CHD (Table 4) [15-18, 20, 21, 25, 27-29, 31, 32, 34, 35, 40]. 
Table 4. Urinary 5-HIAA levels in CHD patients

\begin{tabular}{|c|c|c|c|c|}
\hline First author [Ref.], year & u5-HIAA units of measurement & Baseline u5-HIAA levels in patients with CHD & Baseline u5-HIAA level in patients without CHD & $p$ value (CHD vs. non-CHD) \\
\hline Bergestuen [35], 2009 & $\mu \mathrm{mol} / 24 \mathrm{~h}$ & Median 783 (range 9-2,160) & Median 67.5 (range $0-1,980)$ & $<0.001$ \\
\hline Bernheim [49], 2008 & $\mathrm{mg} / 24 \mathrm{~h}$ & Median 183 (IQR 83-300) & NR & - \\
\hline Connolly [47], 1995 & $\mathrm{mg} / 24 \mathrm{~h}$ & Median 172 (range 2.1-416) & NR & - \\
\hline Denney [17], 1998 & $\mathrm{mg} / 24 \mathrm{~h}$ & $\begin{array}{l}\text { Median } 144.6 \text { (range 99-358); } \\
\text { initially had CHD } \\
\text { Median } 319 \text { (range 193-356); developed CHD }\end{array}$ & $\begin{array}{l}\text { Median } 106.7 \text { (range 59-193); initially no CHD } \\
\text { Median } 77 \text { (range } 42-112 \text { ); } \\
\text { no CHD, no development }\end{array}$ & NS \\
\hline Himelman [15], 1989 & $\mathrm{mg} / 24 \mathrm{~h}$ & $\begin{array}{l}\text { Maximum level: mean } 331 \text { (SD 231) } \\
\text { Mean level: mean } 203 \text { (SD 105) }\end{array}$ & $\begin{array}{l}\text { Maximum level: mean } 58 \text { (SD 78) } \\
\text { Mean level: mean } 47 \text { (SD 75) }\end{array}$ & $\begin{array}{l}\text { Maximum level: }<0.001 \\
\text { Mean level: }<0.001\end{array}$ \\
\hline Hoffmann [18], 2001 & $\mu \mathrm{mol} / 24 \mathrm{~h}$ & Mean 713 (SD 669) & Mean 175 (SD 305) & 0.005 \\
\hline Janson [29], 1997 & $\mu \mathrm{mol} / 24 \mathrm{~h}$ & Mean 814 & Mean: 441 & $<0.001$ \\
\hline Korach [46], 2016 & $\mathrm{mg} / 24 \mathrm{~h}$ & Mean 61 (SD 36) & NR & - \\
\hline Mansencal [21], 2010 & $\mathrm{mg} / 24 \mathrm{~h}$ & Mean 384 (SD 431) & Mean 43 (SD 25) & $<0.0001$ \\
\hline Meijer 2002 [19], & $\mu \mathrm{mol} / \mathrm{mol}$ creatinine & Median 16.5 (range 6.7-200.1) & NR & - \\
\hline Møller [20], 2003 & $\mathrm{mg} / 24 \mathrm{~h}$ & Median 209 (IQR 79-306) & Median 110 (IQR 49-177) & 0.02 \\
\hline Møller [45], 2005 & $\mathrm{mg} / 24 \mathrm{~h}$ & Median 264 (range 187-391) & NR & - \\
\hline Pellikka [16], 1993 & $\mathrm{mg} / 24 \mathrm{~h}$ & Mean 270 (SD 154) & Mean 131 (SD 149) & $<0.001$ \\
\hline Riechelmann [25, 27], 2018 & $\begin{array}{l}\mathrm{mg} / 24 \mathrm{~h} \text { (assumed; reported } \\
\text { as "mg" only in publication) }\end{array}$ & Median 50.8 & Median 25.4 & NS \\
\hline Robiolio [28], 1995 & $\mathrm{mg} / 24 \mathrm{~h}$ & Mean 219 (SD 124) & Mean 55.3 (SD 141) & $<0.0001$ \\
\hline van der Horst-Schrivers [34], 2007 & $\mathrm{mmol} / \mathrm{mol}$ creatinine & Median 52.8 (range 8.5-252.0) & Median 18.6 (range 1.3-418.4) & 0.085 \\
\hline Weingarten [48], 2007 & $\mathrm{mg} / 24 \mathrm{~h}$ & $\begin{array}{l}\text { 1985-1994: median } 206(10 \%, 90 \% \text { quantiles } 12-315) \\
\text { 1995-2003: median } 128(10 \%, 90 \% \text { quantiles } 31-362)\end{array}$ & NR & - \\
\hline Westberg [40], 2001 & $\mu \mathrm{mol} / 24 \mathrm{~h}$ & Mean 635 (SEM 91) & Mean 306 (SEM 105) & NR \\
\hline $\begin{array}{l}\text { Zuetenhorst [31], } 2003 \\
\text { Zuetenhorst [32], } 2004\end{array}$ & $\mu \mathrm{mol} / 24 \mathrm{~h}$ & $\begin{array}{l}\text { 2003: median } 576 \text { (range } 87-1,028 \text { ) } \\
\text { 2004: median } 815 \text { (range } 87-1,185 \text { ) }\end{array}$ & $\begin{array}{l}\text { 2003: Median } 233 \text { (range 17-1,616) } \\
\text { 2004: Median } 206 \text { (range 19-1,116) }\end{array}$ & $\begin{array}{l}\text { 2003: } 0.02 \\
\text { 2004: } 0.007\end{array}$ \\
\hline
\end{tabular}

In the majority of studies, patients with $\mathrm{CHD}$ were found to have mean and median u5-HIAA levels that were greater than double those found in patients without CHD (Fig. 4; variability within individual studies is shown in Table 4). Following conversion to $\mu \mathrm{mol} / 24 \mathrm{~h}$ for studies using $\mathrm{mg} / 24 \mathrm{~h}$, the mean and median baseline levels of u5-HIAA in patients with versus without CHD were 3192,009 versus $175-685 \mu \mathrm{mol} / 24 \mathrm{~h}$, and $266-1,381$ versus $67.5-575 \mu \mathrm{mol} / 24 \mathrm{~h}$, respectively [15-18, 20, 21, 25, 27$29,31,32,35,40,45-49]$. Two studies presented their u5HIAA measurements in mmol or $\mu \mathrm{mol}$ per mole of creatinine and, as such, could not be directly compared [19, 34].

Six studies reported the association of 5-HIAA levels with the progression of CHD [17, 20-23, 39, 40]. Higher u5-HIAA levels (plasma levels in Dobson et al. [23]) were generally associated with disease progression in these studies. The median 5-HIAA level associated with disease progression and/or worsening ranged from 791 to 2,247 $\mu \mathrm{mol} / 24 \mathrm{~h}[17,20,22]$; Westberg et al. [40] presented mean values according to mild, moderate or severe disease, ranging from 408 to $901 \mu \mathrm{mol} / 24 \mathrm{~h}$ (Table 5).

Seven studies performed univariate or multivariate analyses to investigate the association of 5-HIAA levels with CHD development/progression (Table 5) [17, 2023, 39]. Rodríguez Laval et al. [39] observed, in both their univariate and multivariate analyses, that u5-HIAA levels $>501 \mu \mathrm{mol} / 24 \mathrm{~h}$ were a significant risk factor for the development of $\mathrm{CHD}$. Through a multivariate Poisson regression analysis, Bhattacharyya et al. [22] found that the risk of CHD progression in patients with u5-HIAA levels of $300-599,600-899$, and $\geq 900 \mu \mathrm{mol} / 24 \mathrm{~h}$ was $2.74,3.16$, and 3.40 times higher, respectively, than in patients with u5-HIAA levels $<300 \mu \mathrm{mol} / 24 \mathrm{~h}$. A multivariate logistic regression model by Møller et al. [20] showed that, in patients with CHD, peak u5-HIAA level was a significant predictor of a $>25 \%$ change in cardiac score (considered suggestive of disease progression; OR: 1.08 for each in- 


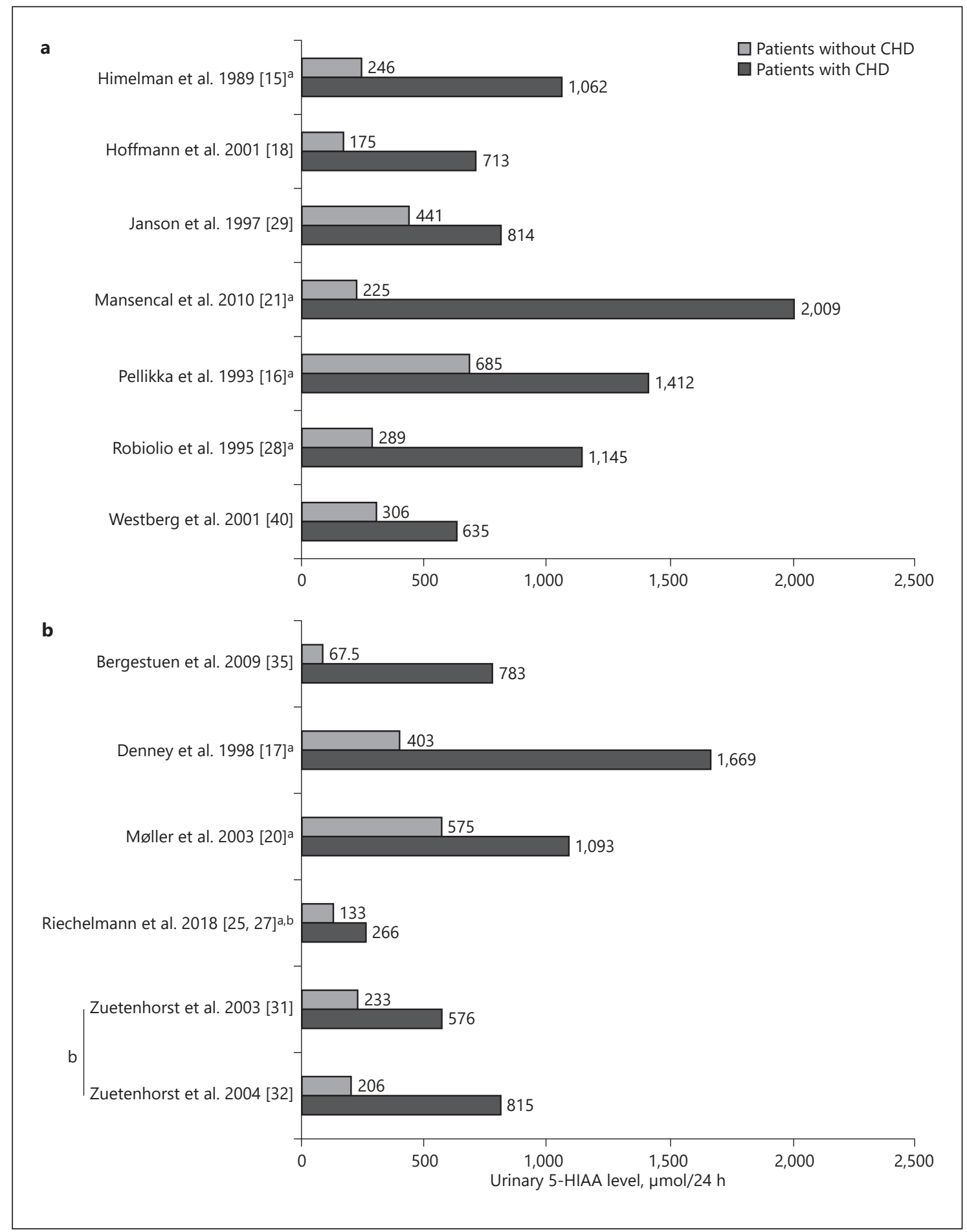

Fig. 4. Mean (a) and median (b) urinary 5-hydroxyindoleacetic acid (5-HIAA) levels in patients with or without carcinoid heart disease (CHD). ${ }^{\text {a }}$ Levels reported in $\mathrm{mg} / 24 \mathrm{~h}$ converted to $\mu \mathrm{mol} / 24 \mathrm{~h}$ for purposes of comparison. ${ }^{b}$ Different publications on the same study. 
Table 5. 5-HIAA levels and CHD progression

\begin{tabular}{|c|c|c|}
\hline First author [Ref.], year & $\begin{array}{l}\text { 5-HIAA units of measure- } \\
\text { ment in urine or plasma }\end{array}$ & 5-HIAA level associated with disease progression \\
\hline Bhattacharyya [22], 2011 & $\mu \mathrm{mol} / 24 \mathrm{~h}$ (urine) & $\begin{array}{l}\text { 5-HIAA level at time of progression: median } 791 \text { (IQR 581-1,084.5) } \\
\text { 5-HIAA level in previous } 6 \text { months for this group: median } 460.5 \text { (IQR } \\
\text { 309-948.5); } p=0.001\end{array}$ \\
\hline Denney [17], 1998 & mg/24 h (urine) & $\begin{array}{l}\text { Patients with CHD progression or development at baseline: median } 256 \\
\text { (range 145-356) } \\
\text { Reference group: median } 98.8 \text { (range 59-186); } p<0.005\end{array}$ \\
\hline Dobson [23], 2014 & $\mathrm{nmol} / \mathrm{L}$ (plasma) & $\begin{array}{l}\text { CHD progression: median 2,247 (range 807-2,939) } \\
\text { No CHD progression: median } 316(138-661) \\
\text { Died prior to second echocardiogram: median 1,221 (range 167-437); } \\
p=0.009\end{array}$ \\
\hline Møller [20], 2003 & $\mathrm{mg} / 24 \mathrm{~h}$ (urine) & $\begin{array}{l}\text { Baseline: } \\
\text { Progressors: median } 166 \text { (IQR 86-303); reference group: median } 115 \\
\text { (IQR 49-212); } p=0.005 \\
\text { Highest value: progressors: median } 265 \text { (IQR 209-593); reference group: } \\
\text { median 189 (IQR 75-286); } p=0.004\end{array}$ \\
\hline Rodríguez Laval [39], 2018 & $\mu \mathrm{mol} / 24 \mathrm{~h}$ (urine) & $\begin{array}{l}\text { 5-HIAA } \geq 501 \mu \mathrm{mol} / 24 \mathrm{~h} \text { as a risk factor for CHD development } \\
\text { Univariate analysis: OR } 17.6(95 \% \text { CI } 4.9-62.8) ; p<0.001 \\
\text { Multivariate analysis: HR } 14.7 \text { (95\% CI 3.8-55.3); } p<0.001\end{array}$ \\
\hline
\end{tabular}

5-HIAA, 5-hydroxyindoleacetic acid; CHD, carcinoid heart disease; CI, confidence interval; HR, hazard ratio; IQR, interquartile range; $\mathrm{NR}$, not reported; $\mathrm{OR}$, odds ratio; $\mathrm{SD}$, standard deviation; $\mathrm{SEM}$, standard error of the mean.

crease of $25 \mathrm{mg} / 24 \mathrm{~h}$; 95\% CI: $1.03-1.13 ; p=0.009)$. Denney et al. [17] reported that mean post-treatment u5-HIAA level was a significant predictor of $\mathrm{CHD}$ progression in a multiple stepwise regression analysis $(p<0.005)$. In a linear regression analysis, Mansencal et al. [21] identified a strong correlation between u5-HIAA levels and CHD severity as scored out of 30 , accounting for rightand left-sided CHD (scored out of 20 and 10, respectively). Through a univariate analysis, Dobson et al. [23] found that every $100 \mathrm{nmol} / \mathrm{L}$ increase in plasma 5-HIAA was associated with a $5 \%$ increase in the odds of $\mathrm{CHD}$ progression before a patient's second follow-up (within a median follow-up period of 27 months; OR: 1.05; 95\% CI: $1.01-1.09 ; p=0.012$ ).

Two studies presented data regarding the association of 5-HIAA levels with CHD mortality (Table 6) [23, 48]. Dobson et al. [23] found that every $100 \mathrm{nmol} / \mathrm{L}$ increase in plasma 5-HIAA was associated with a $7 \%$ increase in the odds of death before second follow-up (OR: 1.07; 95\% CI: $1.03-1.10 ; p=0.001$ ). In a study on patients with CHD, Weingarten et al. [48] found that patients with higher u5HIAA levels had higher mortality rates compared with patients with lower u5-HIAA levels, although the association was not statistically significant (logistic regression, 
Table 6. 5-HIAA levels associated with CHD mortality

\begin{tabular}{|c|c|c|}
\hline First author [Ref.], year & $\begin{array}{l}\text { 5-HIAA units of measurement } \\
\text { in urine or plasma }\end{array}$ & 5-HIAA level and mortality in CHD patients \\
\hline $\begin{array}{l}\text { Dobson [23], } \\
2014\end{array}$ & $\mathrm{nmol} / \mathrm{L}$ (plasma) & $\begin{array}{l}\text { Baseline 5-HIAA concentration was significantly associated with disease progression: } \\
\text { every } 100 \mathrm{nmol} / \mathrm{L} \text { increase in 5-HIAA yielded 7\% higher odds of death before second } \\
\text { follow-up (OR 1.07, 95\% CI: } 1.03-1.10 ; p=0.001)\end{array}$ \\
\hline Weingarten [48], 2007 & $\mathrm{mg} / 24 \mathrm{~h}$ (urine) & $\begin{array}{l}\text { Deaths: } \\
0-6 \mathrm{mg} / 24 \mathrm{~h}: 0 / 2(0 \%) \\
7-100 \mathrm{mg} / 24 \mathrm{~h}: 2 / 27(7 \%) \\
101-200 \mathrm{mg} / 24 \mathrm{h:} 3 / 25(12 \%) \\
201-300 \mathrm{mg} / 24 \mathrm{h:} 6 / 23(26 \%) \\
\text { >300 mg/24 h: } 2 / 12(17 \%) \\
\text { Adjusted } p=0.28 \text { (NS) }\end{array}$ \\
\hline
\end{tabular}

5-HIAA, 5-hydroxyindoleacetic acid; CHD, carcinoid heart disease; CI, confidence interval; NS, not significant; OR, odds ratio.

$p=0.28)$; over the entire study period, patients with u5HIAA levels of $7-100,101-200,201-300$, and $>300 \mathrm{mg} / 24$ $\mathrm{h}$ had mortality rates of $7.4 \%(n=2 / 27), 12.0 \%(n=3 / 25)$, $26.1 \%(n=6 / 23)$, and $16.7 \%(n=2 / 12)$, respectively.

Three studies only included patients who underwent valve replacement surgery [46-48] and 9 studies reported the number of patients with CS or CHD who received valve replacements $[15,16,18,20,22,40,44,45,49]$. Of these, 2 studies correlated the association of 5-HIAA levels with valve replacement surgery [20, 45]. Møller et al. [20] reported 32 patients referred for valve replacement, noting that these patients had significantly higher u5-HIAA levels at baseline $(p=0.01)$ and at their highest recorded value ( $p=0.03$ ) versus patients with $\leq 25 \%$ change in their echocardiogram $(n=46)$. In contrast, Møller et al. [45] reported that in patients undergoing cardiac surgery for dysfunctional valves $(n=87)$, u5-HIAA levels were not significantly different versus medically treated patients $(n=113 ; p=0.83)$.

\section{Quality of Reporting}

The 31 studies identified by this review were generally well reported, as assessed by the STROBE checklist (online suppl. data; Table S5) [13]. However, most studies published in congress proceedings did not provide sufficient information to judge their quality [24-27, 38, 4143]. Additionally, fewer than half of the captured studies described any efforts to reduce bias in their analyses [17, $20-23,34,36,37,39,45,48]$, only 4 studies explained how missing data were addressed [34, 36, 37, 39, 49], only 1 study addressed patients lost to follow-up [23], and only 4 studies indicated the number of participants with missing data for variables of interest $[30,34,36,37,39]$.

\section{Discussion}

We identified over 30 studies on CHD and 5-HIAA levels in this comprehensive and systematic search of medical literature databases, article reference lists, and abstracts from relevant congresses, allowing us to conduct an up-to-date review of the evidence regarding the relationship between 5-HIAA and CHD. CHD incidence and prevalence varied widely between the included studies, with older studies tending to report higher estimates of prevalence and incidence. This could be a result of the less effective management of CS among patients in older studies, as somatostatin analogues may have helped prevent CHD in more recent years [50].

The large range of CHD incidence estimates could also be a result of variation across the study populations. Three studies investigated patients who were referred for echocardiographic evaluation due to suspicion of $\mathrm{CHD}$ $[16,20,25,27]$, and reported incidence estimates of $56 \%$ [16], $49 \%$ [20], and $40 \%$ [25, 27], respectively. This is higher than the median CHD incidence of $24 \%$ taken across all the identified studies and is likely to be due to selection bias. A number of other studies, including those reported by Himelman et al. [15], Hoffmann et al. [18], and Ardill et al. [38], gave high incidence estimates but had small sample sizes.

A small number of studies conducted multivariate analyses to compare the risk of death in patients with and without CHD. Westberg et al. [40] found the risk of death to be higher in patients with TR relative to those without (determined by echocardiography). Norlén et al. [36,37] and Toumpanakis et al. [41-43] reported the risk of death to be significantly higher in patients with $\mathrm{CHD}$, but
Buchanan-Hughes et al. 
Bergestuen et al. [35] did not. Both Bergestuen et al. [35] and Toumpanakis et al. [41-43] examined larger study populations and patients with NETs rather than CS specifically, which could have affected the reported results. For example, Bergestuen et al. [35] investigated the influence of CHD on survival in a relatively large number of patients with NETs who did not have liver metastases or CS. Contrary to the results obtained, the absence of liver metastases and CS would be expected to lead to a longer survival time and potentially a bigger difference in mortality between patients with and without CHD [35]. However, the analysis did not take into account factors other than CHD that could influence patient survival. Contrastingly, Toumpanakis et al. [41-43] adjusted for tumour grade, metastases, and age in their analysis; however, there was a discrepancy between the reported SE and the 95\% CI estimated in our analysis, meaning that the results of this study should be interpreted with caution.

In this SLR, u5-HIAA was found to be consistently higher in patients with CHD compared with those without, and all but 1 of the 6 studies investigating the association between 5-HIAA levels and CHD found that higher levels were significantly associated with disease progression [17, 20, 22, 23, 39]. Increased u5-HIAA levels were also associated with increased mortality in the study by Weingarten et al. [48], although the sample size was small, and no statistically significant trend was observed. Overall, these data suggest that 5-HIAA may be a useful prognostic marker for $\mathrm{CHD}$ and disease progression in patients with CS. A recently conducted narrative review identified a similar body of evidence to this systematic review, corroborating these findings [6].

Taken together, the results of this review indicate that elevated levels of u5-HIAA are associated with increased probability of CHD diagnosis, disease progression, and mortality. This conclusion is supported by a recent systematic review and meta-analysis that reported a quantifiable relationship between increasing u5HIAA levels in patients with NETs and higher risk of 1 -year mortality [51]. There is a need for consistent and practical guidelines for the screening, diagnosis, and management of CHD in clinical practice. However, a consensus on how to avoid the development of CHD among patients with NETs is lacking, in particular for those who also have CS. The reliance on standard echocardiography to diagnose CHD, particularly in older studies, should be considered when comparing with studies that have employed additional criteria to diagnose and identify patients. Alongside 5-HIAA, N-ter- minal pro-B-type natriuretic peptide (NT-proBNP) has been demonstrated as a useful diagnostic and prognostic biomarker for CHD and may be considered in future investigations [6]. The surveillance and management of CHD will become increasingly important as patients with NETs live longer as more effective treatments are developed.

A limitation of the current review was the heterogeneity of the included studies, particularly in terms of study design, population sample size and study duration. This may have been further exacerbated by the high level of heterogeneity in the clinical manifestation of NETs between patients [52]. In addition, only some of the studies reported exclusively on patients with CS and CHD. This is an important consideration, as patients with non-secreting NETs or without liver metastases are at significantly reduced risk of developing CHD $[1,6]$. Ultimately, this heterogeneity prevented any meta-analysis from being conducted. Nevertheless, several studies consistently reported a link between 5-HIAA levels, CHD diagnosis, and their negative impact on patient prognosis, supporting the conclusion that 5-HIAA is a predictive factor for CHD

All except one of the included studies relied on urine samples to ascertain 5-HIAA levels [23]. Urinary sampling generally requires collection over a 24 -hour period, and factors such as patient diet and incomplete urine collection may impact measurements, introducing variability. Furthermore, it is likely that older studies relied on methods with decreased specificity versus contemporary literature. Harmonisation of methods between studies, and the employment of more sophisticated methods such as plasma or serum 5-HIAA sampling would be beneficial for future research; these methods are generally preferred by patients versus 24 -hour collections and have been shown to be consistent with u5-HIAA measurements provided that renal function has been considered [53].

Non-English language publications were excluded unless they had sufficient information in their English abstracts. However, of the small number of non-English language articles that were identified in the database searches, most were of an irrelevant publication type or study design (e.g., case study or narrative review); hence, only a limited proportion of these non-English articles may have had outcomes that would have been of interest to this review. 


\section{Conclusions}

Although the heterogeneity and individual limitations of the included studies should be taken into consideration when interpreting the results of this review, the identified evidence indicates that elevated 5-HIAA levels are linked to an increased likelihood of CHD development and disease progression, and an increased risk of mortality. CHD was also found to be a significant predictor of death in a number of studies. The development of standardised screening tools for CHD and careful management of 5-HIAA levels could be important considerations for future clinical practice, and beneficial for this patient population.

\section{Acknowledgements}

The authors gratefully acknowledge the contribution of Michele Kohli, Jennifer Haig, and Laura Pastor, who were all employees of OptumInsight at the time of this work, who conducted an earlier scoping review on this topic, and performed the initial data extractions for a number of the included publications. The authors thank Ines Neves, MSc, and Amelia Frizell-Armitage, PhD, of Costello Medical, Cambridge, UK, for providing medical writing and editorial support, which was sponsored by Ipsen Pharma (Boulogne-Billancourt, France) in accordance with Good Publication Practice guidelines.

\section{Disclosure Statement}

A.B.H. and A.P: employees of Costello Medical; M.F., F.M: employees of Ipsen; D.M.P: consultancy fees from Ipsen and Advanced Accelerator Applications; S.S: honorarium from Ipsen and Novartis; research funding/fellowship support from Novartis, Merck EMD Serono, Ipsen, and Pfizer.

\section{Funding Sources}

This study was sponsored by Ipsen.

\section{Author Contributions}

Substantial contributions to study conception/design, or acquisition/analysis/interpretation of data: A.B.H., A.P., M.F., F.M., D.M.P., S.S.; drafting of the publication, or revising it critically for important intellectual content: A.B.H., A.P., M.F., F.M., D.M.P., S.S.; final approval of the publication: A.B.H., A.P., M.F., F.M., D.M.P., S.S.

\section{Data Sharing Statement}

This study is an SLR and no novel data were generated. All data relevant to the study are either included in the article or uploaded as supplementary information.

\section{References}

1 Grozinsky-Glasberg S, Grossman AB, Gross DJ. Carcinoid Heart Disease: From Pathophysiology to Treatment-'Something in the Way It Moves'. Neuroendocrinology. 2015; 101(4):263-73.

2 Dasari A, Shen C, Halperin D, Zhao B, Zhou $\mathrm{S}, \mathrm{Xu} \mathrm{Y}$, et al. Trends in the Incidence, Prevalence, and Survival Outcomes in Patients With Neuroendocrine Tumors in the United States. JAMA Oncol. 2017 Oct;3(10):133542.

3 Halperin DM, Shen C, Dasari A, Xu Y, Chu Y, Zhou $S$, et al. Frequency of carcinoid syndrome at neuroendocrine tumour diagnosis: a population-based study. Lancet Oncol. 2017 Apr;18(4):525-34.

4 Fox DJ, Khattar RS. Carcinoid heart disease: presentation, diagnosis, and management. Heart. 2004 Oct;90(10):1224-8.

5 Modlin IM, Oberg K, Chung DC, Jensen RT, de Herder WW, Thakker RV, et al. Gastroenteropancreatic neuroendocrine tumours. Lancet Oncol. 2008 Jan;9(1):61-72.

6 Davar J, Connolly HM, Caplin ME, Pavel M, Zacks J, Bhattacharyya S, et al. Diagnosing and Managing Carcinoid Heart Disease in Patients With Neuroendocrine Tumors: An Ex- pert Statement. J Am Coll Cardiol. 2017 Mar; 69(10):1288-304

7 Pape UF, Perren A, Niederle B, Gross D, Gress T, Costa F, et al.; Barcelona Consensus Conference participants. ENETS Consensus Guidelines for the management of patients with neuroendocrine neoplasms from the jejuno-ileum and the appendix including goblet cell carcinomas. Neuroendocrinology. 2012;95(2):135-56.

8 Rubin de Celis Ferrari AC, Glasberg J, Riechelmann RP. Carcinoid syndrome: update on the pathophysiology and treatment. Clinics (Sao Paulo). 2018 Aug;73 suppl 1:e490s.

9 Strosberg JR, Benson AB, Huynh L, Duh MS, Goldman J, Sahai V, et al. Clinical benefits of above-standard dose of octreotide LAR in patients with neuroendocrine tumors for control of carcinoid syndrome symptoms: a multicenter retrospective chart review study. Oncologist. 2014 Sep;19(9): 930-6.

10 Forero Molina MA, Garcia E, Gonzalez-Devia D, García-Duperly R, Vera A. A 17-year-old male with a Small Bowel Neuroendocrine Tumor: flushing differential diagnosis. World Allergy Organ J. 2017 Sep;10(1):30.
11 Higgins J, Thomas J, Chandler J, Cumpston M, Li T, Page M, et al. Cochrane Handbook for Systematic Reviews of Interventions Version 5.0.2 [updated Sept 2009] [accessed: 2016 Mar 14]. The Cochrane Collaboration. Available from: wwwtrainingcochraneorg/handbook.

12 Centre for Reviews and Dissemination. Systematic Reviews: CRD's guidance for undertaking reviews in health care. York: Centre for Reviews and Dissemination, University of York; 2008.

13 von Elm E, Altman DG, Egger M, Pocock SJ, Gøtzsche PC, Vandenbroucke JP; STROBE Initiative. Strengthening the Reporting of Observational Studies in Epidemiology (STROBE) statement: guidelines for reporting observational studies. BMJ. 2007 Oct; 335(7624):806-8.

14 Davis Z, Moertel CG, McIlrath DC. The malignant carcinoid syndrome. Surg Gynecol Obstet. 1973 Oct;137(4):637-44.

15 Himelman RB, Schiller NB. Clinical and echocardiographic comparison of patients with the carcinoid syndrome with and without carcinoid heart disease. Am J Cardiol. 1989 Feb;63(5):347-52. 
16 Pellikka PA, Tajik AJ, Khandheria BK, Seward JB, Callahan JA, Pitot HC, et al. Carcinoid heart disease. Clinical and echocardiographic spectrum in 74 patients. Circulation. 1993 Apr;87(4):1188-96.

17 Denney WD, Kemp WE Jr, Anthony LB, Oates JA, Byrd BF 3rd. Echocardiographic and biochemical evaluation of the development and progression of carcinoid heart disease. J Am Coll Cardiol. 1998 Oct;32(4):101722.

18 Hoffmann J, Grimm W, Menz V, Wied M, Sprenger A, Arnold R, et al. Prognostic value of heart rate variability analysis in patients with carcinoid syndrome. Digestion. 2001; 63(1):35-42.

19 Meijer WC, van Veldhuisen DJ, Kema IP, Van den Berg MP, Boomsma F, Willemse PH, et al. Cardiovascular abnormalities in patients with a carcinoid syndrome. Neth J Med. 2002 Mar;60(1):10-6.

20 Møller JE, Connolly HM, Rubin J, Seward JB, Modesto K, Pellikka PA. Factors associated with progression of carcinoid heart disease. $\mathrm{N}$ Engl J Med. 2003 Mar;348(11):1005-15.

21 Mansencal N, Mitry E, Bachet JB, Rougier P, Dubourg O. Echocardiographic follow-up of treated patients with carcinoid syndrome. Am J Cardiol. 2010 Jun;105(11):1588-91.

22 Bhattacharyya S, Toumpanakis C, Chilkunda D, Caplin ME, Davar J. Risk factors for the development and progression of carcinoid heart disease. Am J Cardiol. 2011 Apr;107(8): 1221-6.

23 Dobson R, Burgess MI, Valle JW, Pritchard DM, Vora J, Wong C, et al. Serial surveillance of carcinoid heart disease: factors associated with echocardiographic progression and mortality. Br J Cancer. 2014 Oct;111(9):1703-9.

24 d'Arienzo PD, Amir E, Lewis AR, Magdalani L, Mansoor W, Hubner RA, et al. Carcinoid syndrome: patient outcomes from a European Neuroendocrine Tumour Society (ENETs) centre of excellence. Ann Oncol. 2017 Sep;28 Supplement 5:v148.

25 Mesquita MC, Silva CA, Silva CM, Feres Almeida Soeiro MC, Hajjar LA, Gehm Hoff PM, et al. High hepatic tumor burden and cardiovascular comorbidities linked to carcinoid heart disease. Ann Oncol. 2017 Sep;28 Supplement 5:v149.

26 Fijalkowski R, Singh A, Baum R, Kulkarni H, Niepsch K, Kaemmerer D, et al. Carcinoid Syndrome Open Questions-Evaluations from a Real Life Setting. Neuroendocrinology. 2018; 106:76.

27 Riechelmann R, Mesquita M, Alves C, Silva C, Soeiro M, Luca R, et al. High Hepatic Tumor Burden and History of Cardiovascular Comorbidities Are Associated with Carcinoid Heart Disease: A Multicenter and Multinational Study. Neuroendocrinology. 2018;106: 115.

28 Robiolio PA, Rigolin VH, Wilson JS, Harrison JK, Sanders LL, Bashore TM, et al. Carcinoid heart disease. Correlation of high serotonin levels with valvular abnormalities detected by cardiac catheterization and echocardiography. Circulation. 1995 Aug;92(4):790-5.

29 Janson ET, Holmberg L, Stridsberg M, Eriksson B, Theodorsson E, Wilander E, et al. Carcinoid tumors: analysis of prognostic factors and survival in 301 patients from a referral center. Ann Oncol. 1997 Jul;8(7):685-90.

30 Kinney MA, Warner ME, Nagorney DM, Rubin J, Schroeder DR, Maxson PM, et al. Perianaesthetic risks and outcomes of abdominal surgery for metastatic carcinoid tumours. $\mathrm{Br}$ J Anaesth. 2001 Sep;87(3):447-52.

31 Zuetenhorst JM, Bonfrer JM, Korse CM, Bakker R, van Tinteren H, Taal BG. Carcinoid heart disease: the role of urinary 5-hydroxyindoleacetic acid excretion and plasma levels of atrial natriuretic peptide, transforming growth factor-beta and fibroblast growth factor. Cancer. 2003 Apr;97(7):1609-15.

32 Zuetenhorst JM, Korse CM, Bonfrer JM, Bakker RH, Taal BG. Role of natriuretic peptides in the diagnosis and treatment of patients with carcinoid heart disease. Br J Cancer. 2004 Jun;90(11):2073-9.

33 Nykjaer KM, Grønbaek H, Nielsen DT, Christiansen P, Astrup LB. Description of patients with midgut carcinoid tumours: clinical database from a Danish centre. In Vivo. 2007 JulAug;21(4):679-84.

34 van der Horst-Schrivers AN, Post WJ, Kema IP, Links TP, Willemse PH, Wymenga AN, et al. Persistent low urinary excretion of 5-HIAA is a marker for favourable survival during follow-up in patients with disseminated midgut carcinoid tumours. Eur J Cancer. 2007 Dec; 43(18):2651-7.

35 Bergestuen DA, Aabakken L, Holm K, Vatn M, Thiis-Evensen E. Small intestinal neuroendocrine tumors: prognostic factors and survival. Scand J Gastroenterol. 2009;44(9): 1084-91.

36 Norlén O, Stålberg P, Öberg K, Eriksson J, Hedberg J, Hessman O, et al. Long-term results of surgery for small intestinal neuroendocrine tumors at a tertiary referral center. World J Surg. 2012 Jun;36(6):1419-31.

37 Norlén O, Stålberg P, Zedenius J, Hellman P. Outcome after resection and radiofrequency ablation of liver metastases from small intestinal neuroendocrine tumours. Br J Surg. 2013 Oct;100(11):1505-14.

38 Ardill J, Stronge W, McCance D, Johnston B. Biomarkers in late stage neuroendocrine tumors of the small bowel. Pancreas. 2016 Mar; 45(3):470.

39 Rodríguez Laval V, Pavel M, Steffen IG, Baur AD, Dilz LM, Fischer C, et al. Mesenteric Fibrosis in Midgut Neuroendocrine Tumors: Functionality and Radiological Features. Neuroendocrinology. 2018;106(2):139-47.

40 Westberg $\mathrm{G}$, Wängberg $\mathrm{B}$, Ahlman $\mathrm{H}$, Bergh $\mathrm{CH}$, Beckman-Suurküla M, Caidahl K. Prediction of prognosis by echocardiography in patients with midgut carcinoid syndrome. $\mathrm{Br}$ J Surg. 2001 Jun;88(6):865-72.

41 Toumpanakis C, Vlachou E, Ramakrishnan S, Phillips E, Tuck A, Wilkins D, et al. Predictive factors for survival in patients with advanced small bowel neuroendocrine tumours. Neuroendocrinology. 2016;103 Supplement 1:27.

42 Toumpanakis C, Vlachou E, Ramakrishnan S, Phillips E, Wilkins D, Tuck A, et al. Predictive factors for survival in patients with advanced small bowel neuroendocrine tumours. Gastroenterology. 2016 April;150:S207.

43 Toumpanakis C, Vlachou E, Wilkins D, Tuck A, Phillips E, Ramakrishnan S, et al. Epidemiological Factors at Diagnosis in a Large Cohort of Patients with Small Bowel Neuroendocrine Tumours. Neuroendocrinology. 2016;103:34.

44 Makridis C, Ekbom A, Bring J, Rastad J, Juhlin C, Oberg K, et al. Survival and daily physical activity in patients treated for advanced midgut carcinoid tumors. Surgery. 1997 Dec; 122(6):1075-82.

45 Møller JE, Pellikka PA, Bernheim AM, Schaff HV, Rubin J, Connolly HM. Prognosis of carcinoid heart disease: analysis of 200 cases over two decades. Circulation. 2005 Nov;112(21): 3320-7.

46 Korach A, Grozinsky-Glasberg S, Atlan J, Dabah A, Atlan K, Rudis E, et al. Valve Replacement in Patients with Carcinoid Heart Disease: Choosing the Right Valve at the Right Time. J Heart Valve Dis. 2016;25(3):349-55.

47 Connolly HM, Nishimura RA, Smith HC, Pellikka PA, Mullany CJ, Kvols LK. Outcome of cardiac surgery for carcinoid heart disease. J Am Coll Cardiol. 1995 Feb;25(2):410-6.

48 Weingarten TN, Abel MD, Connolly HM, Schroeder DR, Schaff HV. Intraoperative management of patients with carcinoid heart disease having valvular surgery: a review of one hundred consecutive cases. Anesth Analg. 2007 Nov;105(5):1192-9.

49 Bernheim AM, Connolly HM, Rubin J, Møller JE, Scott CG, Nagorney DM, et al. Role of Hepatic Resection for Patients With Carcinoid Heart Disease. Mayo Clin Proc. 2008;83(2): 143-50.

50 Hayes AR, Davar J, Caplin ME. Carcinoid Heart Disease: A Review. Endocrinol Metab Clin North Am. 2018 Sep;47(3):671-82.

51 Joish VN, Shah S, Tierce JC, Patel D, McKee C, Lapuerta $\mathrm{P}$, et al. Serotonin levels and 1-year mortality in patients with neuroendocrine tumors: a systematic review and meta-analysis. Future Oncol. 2019 Apr;15(12):1397-406.

52 Singh S, Asa SL, Dey C, Kennecke H, Laidley $D$, Law C, et al. Diagnosis and management of gastrointestinal neuroendocrine tumors: an evidence-based Canadian consensus. Cancer Treat Rev. 2016 Jun;47:32-45.

53 Adaway JE, Dobson R, Walsh J, Cuthbertson DJ, Monaghan PJ, Trainer PJ, et al. Serum and plasma 5-hydroxyindoleacetic acid as an alternative to 24 -h urine 5-hydroxyindoleacetic acid measurement. Ann Clin Biochem. 2016 Sep;53(Pt 5):554-60.

54 Hackshaw A. Statistical Formulae for Calculating Some 95\% Confidence Intervals. A Concise Guide to Clinical Trials. Hoboken: Wiley; 2009. p. 205-7. 